\title{
Trace Elements levels in Rhodophyta algae from Tenerife, Ca- nary Islands (North Atlantic Ocean region)
}

\author{
Soraya Paz Montelongo *, Carmen Rubio, Inmaculada Frías, Ángel J. Gutiérrez, Dailos González-Weller and Ar- \\ turo Hardisson
}

Publisher's Note: MDPI stays neutral with regard to jurisdictional

claims in published maps and institutional affiliations.

\author{
1. Department of Toxicology, University of La Laguna, La Laguna, Tenerife, Canary Islands, Spain 38071, \\ Spain \\ * Correspondence: author: spazmont@ull.edu.es
}

\begin{abstract}
Canary Islands, located in the North Atlantic Ocean, stand out for its great algae diversity and its climatic conditions. However, anthropogenic activities could increase the marine pollution. Some trace elements could pose a risk to biodiversity. Asparagopsis spp and Liagora spp algae, both from Rhodophyta or red algae group, are frequent in the Canary Islands' coasts. So, the trace elements determination in both algae genera is interesting because due to their abundance these algae could be effective bio-indicators of marine pollution. The content of trace elements $(\mathrm{B}, \mathrm{Ba}, \mathrm{Co}, \mathrm{Cr}$, $\mathrm{Cu}, \mathrm{Fe}, \mathrm{Li}, \mathrm{Mn}, \mathrm{Mo}, \mathrm{Ni}, \mathrm{Sr}, \mathrm{V}, \mathrm{Zn}, \mathrm{Al}, \mathrm{Cd}, \mathrm{Pb}$ ) was determined in 30 samples of red algae (Asparagopsis spp and Liagora spp) from Porís de Abona (Arico, Tenerife, Spain) using inductively coupled plasma atomic emission spectroscopy (ICP-OES). Liagora spp recorded the highest mean concentrations of $\mathrm{Fe}(1190 \pm 1545 \mathrm{mg} / \mathrm{kg}$ dry weight $)$ and B $(80.2 \pm 34.2 \mathrm{mg} / \mathrm{kg} \mathrm{dw}) . \mathrm{Al}(288 \pm 157 \mathrm{mg} / \mathrm{kg} \mathrm{dw})$ stands out in Asparagopsis spp. The high concentrations found indicate a high level of contamination of the collected area. Considering that this area is known by its marine diversity, actions must be taken to reduce pollution in this area of environmental interest.
\end{abstract}

Keywords : Trace elements; macroalgae; environmental risk; Canary Islands; marine pollution
Copyright: ( 2021 by the authors. Submitted for possible open access publication under the terms and conditions of the Creative Commons Attribution (CC BY) license (http://creativecommons.org/licenses/by/4.0/). 